\title{
Heterogeneous Uptake of Amines by Citric Acid and Humic Acid
}

\author{
Yongchun Liu, ${ }^{\dagger}$ Qingxin $\mathrm{Ma},{ }^{\dagger}$ and Hong $\mathrm{He}^{*}{ }^{\dagger}$ \\ ${ }^{\dagger}$ Research Center for Eco-Environmental Sciences, Chinese Academy of Sciences, Beijing 100085, China
}

\section{Supporting Information}

ABSTRACT: Heterogeneous uptake of methylamine (MA), dimethylamine (DMA), and trimethylamine (TMA) onto citric acid and humic acid was investigated using a Knudsen cell reactor coupled to a quadrupole mass spectrometer at $298 \mathrm{~K}$. Acid-base reactions between amines and carboxylic acids were confirmed. The observed uptake coefficients of MA, DMA, and TMA on citric acid at $298 \mathrm{~K}$ were measured to be $7.31 \pm 1.13 \times 10^{-3}, 6.65 \pm$ $0.49 \times 10^{-3}$, and $5.82 \pm 0.68 \times 10^{-3}$, respectively, and showed independence of sample mass. The observed uptake coefficients of MA, DMA, and TMA on humic acid at $298 \mathrm{~K}$ increased linearly with sample mass, and the true uptake coefficients of MA, DMA, and TMA were measured to be $1.26 \pm 0.07 \times 10^{-5}$, $7.33 \pm 0.40 \times 10^{-6}$, and $4.75 \pm 0.15 \times 10^{-6}$, respectively. Citric acid, having stronger acidity, showed a higher reactivity than humic acid for a given amine; while the steric effect of amines was found to govern the reactivity between amines and citric acid or humic acid.

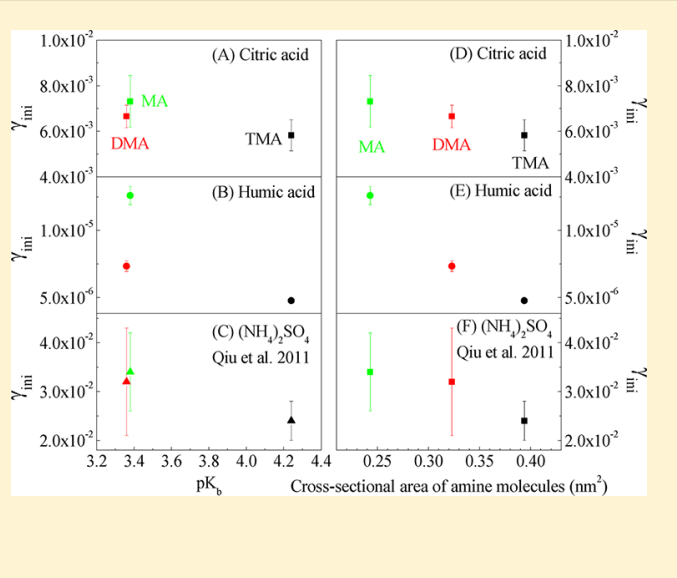

\section{INTRODUCTION}

Amines are frequently detected in atmospheric particulate matter $(\mathrm{PM})^{1-3}$ and are emitted into the atmosphere from a variety of sources including animal husbandry, biomass burning, sewage treatment, meat cooking, automobiles, industrial processes, and marine organisms. ${ }^{4,5}$ The ambient concentration of amines varies from site to site, ${ }^{5}$ and the typical concentration of alkylamines is $<0.02-0.34 \mathrm{ppbv}$, compared with $\sim 25 \mathrm{ppbv}$ of ammonia. ${ }^{6}$ Recently, much attention has been paid to the atmospheric chemistry of amines because of their role in new particle formation (NPF). ${ }^{7-10}$ For example, Smith and coworkers ${ }^{8}$ have found that organic aminium salts can explain $23 \%$ and $47 \%$ of the observed NPF in Hyytiälä on March 21, 2006 and in Tecamac on April 9, 2007, respectively.

Several studies have confirmed the displacement reaction between amines and ammonium salts. ${ }^{11-16}$ The relatively large uptake coefficients $(\gamma)$ of amines on ammonium salts, around unity for reactions with $\mathrm{NH}_{4} \mathrm{NO}_{3}$ clusters ${ }^{11}$ and $10^{-3}-10^{-2}$ for reactions with $\mathrm{NH}_{4} \mathrm{NO}_{3},\left(\mathrm{NH}_{4}\right)_{2} \mathrm{SO}_{4}$, and $\mathrm{NH}_{4} \mathrm{Cl}$ on large particle size $(>100 \mathrm{~nm}),{ }^{14-16}$ imply the importance of displacement reactions in the source of particulate amines. The gaseous amines may undergo acid-base reaction with acids $\left(\mathrm{H}_{2} \mathrm{SO}_{4}, \mathrm{HNO}_{3}, \mathrm{NH}_{4} \mathrm{HSO}_{4}\right.$, and organic acids, etc. $)$ to form salt particles. ${ }^{11,17-19}$ For example, Murphy et al. ${ }^{19}$ observed rapid particle nucleation when amines were injected into a chamber containing gaseous nitric acid. The $\gamma$ of methylamine (MA), dimethylamine (DMA), and trimethylamine (TMA) are in the range of $2.0 \times 10^{-2}-4.4 \times 10^{-2}$ on 59-82 wt $\% \mathrm{H}_{2} \mathrm{SO}_{4}$ film, ${ }^{10}$ and the $\gamma$ are very close to unity for reactions of amines with sulfuric acid or $\mathrm{NH}_{4} \mathrm{HSO}_{4}$ clusters. ${ }^{11,17}$ The large uptake coefficients also highlight the important role of acid-base reaction as a source of particulate amines.
Organic aerosol (OA) is a substantial fraction $(20-90 \%)$ of the nonrefractory $\mathrm{PM}^{20,21}$ Carboxylic acids are present in urban, rural, and remote atmospheric PM and sometimes account for more than $30 \%$ of OA mass. ${ }^{1,22,23}$ Both primary emission and secondary transformation from precursors contribute to particulate carboxylic acids. ${ }^{22,24,25}$ Thus, carboxylic acids were identified with a wide range of molecular weights and complex structures in PM. ${ }^{23,26-30}$ Although it is widely recognized that acid-base reactions between carboxylic acids and amines may occur in the atmosphere, to the best of our knowledge, the reaction kinetics of amines with carboxylic acids present in PM has not been reported yet.

Citric acid was found in atmospheric PM. ${ }^{31}$ On the other hand, humic-like substances (HULIS) were also found as a major part of the OA in urban fine PM. ${ }^{32,33}$ In this study, we investigated the heterogeneous uptake of MA, DMA, and TMA on citric acid and humic acid as representatives of carboxylic acids present in atmospheric PM. $\gamma$ were measured at $298 \mathrm{~K}$ using a Knudsen cell reactor coupled to a quadrupole mass spectrometer (QMS). The effects including acidity of acids and steric hindrance on the reactivity and the atmospheric implications of the present results are discussed.

\section{EXPERIMENTAL DETAILS}

A Knudsen cell reactor coupled to a QMS (KCMS, Hiden, HAL 3F PIC) with EI ionization source $(70 \mathrm{eV})$ has been described in detail elsewhere. ${ }^{34-37}$ It was briefly described in the SI. The finely ground powder samples (<80 mesh) were

Received: June 15, 2012

Revised: August 29, 2012

Accepted: September 10, 2012

Published: September 10, 2012 
dispersed evenly on the Teflon sample holder and then outgassed at $298 \mathrm{~K}$ for $8 \mathrm{~h}$ to reach a base pressure of approximately $5.0 \times 10^{-7}$ Torr. After the sample cover was closed, amine gas from aqueous solution was introduced into the reactor chamber through the leak valve. The pressure in the reactor, which was controlled by the leak valve and measured using the absolute pressure transducer, was $3.0 \pm 0.2 \times 10^{-5}$ Torr. The concentration of amines in the reactor was estimated to be around $15 \mathrm{ppbv}$. Prior to the experiments, the reactor chamber was passivated with amines for 90 min until a steady state QMS signal was established as the samples were isolated from the gas by the sample cover. The observed uptake coefficients $\left(\gamma_{\text {obs }}\right)$ were calculated based on the Knudsen cell equation $^{38-40}$

$$
\gamma_{\mathrm{obs}}=\frac{A_{\mathrm{h}}}{A_{\mathrm{g}}} \cdot \frac{I_{0}-I}{I}
$$

where $A_{\mathrm{h}}$ is the effective area of the escape aperture $\left(\mathrm{cm}^{2}\right) ; A_{\mathrm{g}}$ is the geometric area of the sample holder $\left(\mathrm{cm}^{2}\right)$; and $I_{0}$ and $I$ are the mass spectral intensities with the sample holder closed and open, respectively.

In order to confirm the nonvolatility of the carboxylic acids used in this study, mass spectra of citric acid and humic acid under vacuum in the chamber were measured in a scan mode at $1.0 \times 10^{-6}$ Torr and at $298 \mathrm{~K}$. Desorption of carboxylic acids was not observed under our experimental conditions. According to the fragmentation patterns of amines (NIST), two mass channels with the strongest intensity, i.e. $m / e=30$ and $m / e=31$ for MA, $m / e=44$ and $m / e=45$ for DMA, and $m / e=58$ and $m / e=59$ for TMA, were scanned in a selective ion monitoring (SIM) mode for each kind of amine during the corresponding uptake experiments. For uptake experiments on citric acid, the mass channel for $m / e=129$ (citric acid) was also scanned; no changes were found during the whole experimental time.

40 wt \% of MA in aqueous solution (Alfa Aesar), 30 wt \% of DMA, and 25\% of TMA in aqueous solution (Aldrich) were used for generating amine vapors. Analytical grade citric acid monohydrate (AR, Sinopharm Chemical Reagent Co., Ltd.) and chemical grade humic acid (CR, Sinopharm Chemical Reagent Co., Ltd.) were used after being finely ground. Their specific surface areas (N2-BET) were measured to be 0.96 and $2.24 \mathrm{~m} 2 \cdot \mathrm{g}^{-1}$, respectively, using a Quantachrome Autosorb-1-C instrument. The strong $\mathrm{G}$ and $\mathrm{D}$ bands in Raman spectra (measured with a UVR DLPC-DL-03 with $532 \mathrm{~nm}$ laser) confirmed the presence of the typical aromatic structure in humic acid, and the infrared spectra (measured with a NEXUS 670, Thermo Nicolet Instrument Corp.) also confirmed the carboxylic group presenting in the sample.

\section{RESULTS AND DISCUSSION}

Uptake of Amines onto Citric Acid and Humic Acid. After a steady-state QMS signal was established at $3.0 \pm 0.2 \times$ $10^{-5}$ Torr of amine vapor in the reactor, the particle sample was exposed to gaseous amines by opening the sample cover. Figures 1 and 2 show the typical mass spectral profiles for uptake of amines onto citric acid and humic acid, respectively. In these two figures, (A) and (B) show the uptake curves of MA; (C) and (D) are the uptake curves of DMA; (E) and (F) show the uptake curves of TMA.

As shown in Figures 1 and 2, when the citric acid and humic acid samples were exposed to amines, an immediate decrease in
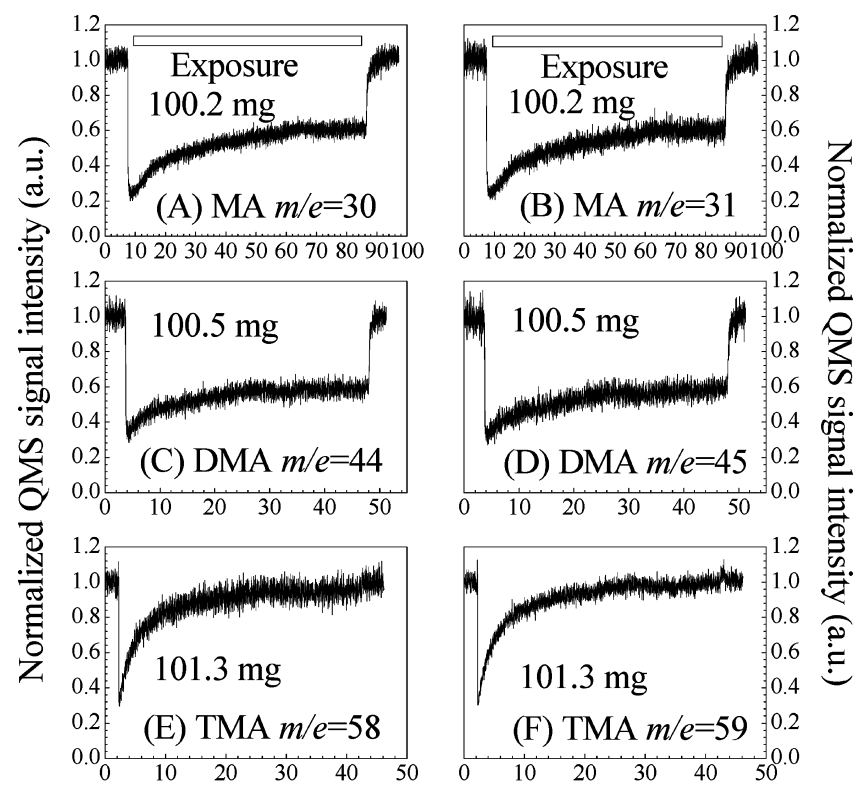

Time (min)

Figure 1. Mass spectral profiles for uptake of amines onto citric acid at $298 \mathrm{~K}$. (A) and (B) MA on $100.2 \mathrm{mg}$ of citric acid; (C) and (D) DMA on $100.5 \mathrm{mg}$ of citric acid; (E) and (F) TMA on $101.3 \mathrm{mg}$ of citric acid.

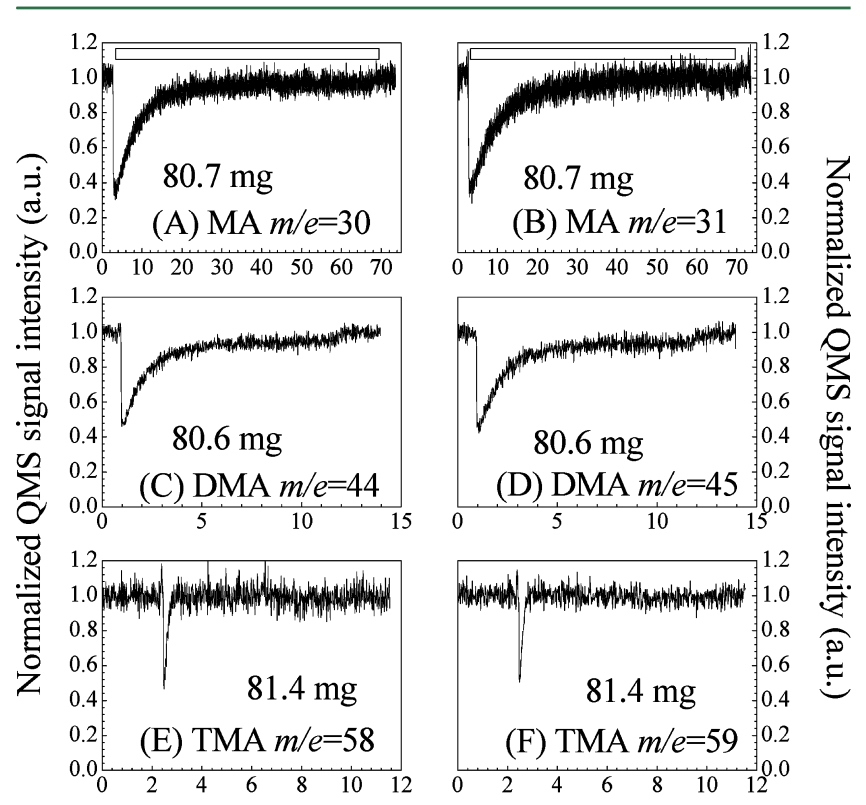

Time (min)

Figure 2. Mass spectral profiles for uptake of amines onto humic acid at $298 \mathrm{~K}$. (A) and (B) MA on $80.7 \mathrm{mg}$ of humic acid; (C) and (D) DMA on $80.6 \mathrm{mg}$ of humic acid; (E) and (F) TMA on $81.4 \mathrm{mg}$ of humic acid.

mass spectral intensity was observed for all of these amines. This confirms the heterogeneous acid-base reaction between amines and organic acids as expected. The different fragments of amine molecules, one on the left and one on the right column in Figures 1 and 2, show similar profiles with exposure time. In Figure 1, the lowest values of the normalized QMS signal $\left(\mathrm{I} / \mathrm{I}_{0}\right)$ are $0.203 \pm 0.002,0.280 \pm 0.005$, and $0.306 \pm$ 0.002 for MA, DMA, and TMA on citric acid, respectively. 
They are $0.323 \pm 0.014,0.442 \pm 0.022$, and $0.465 \pm 0.002$ on humic acid (Figure 2), respectively. With an increase in exposure time, the QMS signals of amines in both Figure 1 and Figure 2 increase notably owing to the consumption of available reactive sites. In Figure $1 \mathrm{E}$ and $\mathrm{F}$, the QMS signal of TMA comes back to its baseline eventually (40 min), and it does so for all of these amines on humic acid, with different saturation times (19, 10, and $1 \mathrm{~min}$ for MA, DMA, and TMA, respectively) (Figure 2). However, the recovery rates of MA and DMA on citric acid are very slow (Figure 1A-D). For example, the normalized QMS signal of MA is still around 0.6 even when citric acid was exposed to MA for $80 \mathrm{~min}$ as shown in Figure $1 \mathrm{~A}$ and B. Compared to citric acid, humic acid showed a larger initial $\mathrm{I} / \mathrm{I}_{0}$ and a shorter saturation time for a given kind of amine. These results imply that the structures of both amines and carboxylic acids have effects on the apparent reactivity.

When the QMS signal intensity (I) is calibrated with the molecular flow rate $\left(\mathrm{mol} \cdot \mathrm{s}^{-1}\right)$, the amount of amine uptake onto each particle sample can be calculated using the integrated area from the uptake curves. ${ }^{41}$ The uptake was $\sim 1.1 \times 10^{-7}$, $\sim 1.7 \times 10^{-8}$, and $\sim 9.6 \times 10^{-10}$ mole for MA, DMA, and TMA on $\sim 80 \mathrm{mg}$ of humic acid, respectively. These values represent the saturation capacity of amines on humic acid under our experimental conditions. For humic acid, the saturation capacity of amines decreases significantly with the increase in the number of methyl groups in an amine molecule. The amount of MA consumed by $100.2 \mathrm{mg}$ of citric acid was $\sim 6.6 \times 10^{-7}$ mole for $80 \mathrm{~min}$ of reaction time. It was $\sim 2.7 \times 10^{-7}$ mole for DMA consumed by $100.5 \mathrm{mg}$ of citric acid for $40 \mathrm{~min}$ of exposure time, and $\sim 5.5 \times 10^{-8}$ mole for TMA on $101.3 \mathrm{mg}$ of citric acid for $30 \mathrm{~s}$ of exposure time. If all of the three carboxylic groups in a citric acid molecule (shown in Figure S1) are stoichiometrically involved in the acid-base reaction, the reaction degrees of the amines on citric acid are estimated to be $\sim 0.034 \%$ for MA, $\sim 0.011 \%$ for DMA, and $\sim 0.002 \%$ for TMA within the reaction time. This means that only a very small fraction of the carboxylic groups is consumed during the uptake experiments. Because the molecular weight of humic acid is unknown, the reaction degrees cannot be calculated in this study.

Reaction Kinetics. Figure 3 shows the evolution of $\gamma_{\text {obs }}$ of these three amines on citric acid and humic acid as a function of exposure time. $\gamma_{\text {obs }}$ was calculated using eq 1 . The left and right columns correspond to citric acid and humic acid, respectively. Because two mass channels were scanned for each kind of amine during the uptake experiments, the $\gamma_{\text {obs }}$ based on both of them were calculated and are shown in black and red color. As can be seen from Figure 3, the red lines coincide very well with the black ones. In the following section, the uptake coefficients based on $m / e=30, m / e=44$, and $m / e=59$ were reported for uptake of MA, DMA, and TMA, respectively. The $\gamma_{\text {obs }}$ for all of these amines decrease with exposure time corresponding to the recovery of the mass spectral signal of the amines as shown in Figures 1 and 2. Table 1 summarizes the initial $\gamma_{\text {obs }}$ of amines on citric acid and humic acid at $298 \mathrm{~K}$. The uncertainties of $\gamma_{\text {obs }}$ with each sample mass are the $\sigma$ of three repeat experiments, and the others are the statistical $\sigma$. The observed initial $\gamma_{\text {obs }}$ varies from $1.0 \times 10^{-3}$ to $8.0 \times 10^{-3}$ depending on sample mass and reaction system.

In the Knudsen cell reactor, the effect of the diffusion of reactive molecules from the gas-phase to the particle surface is eliminated because the molecular flow regime is realized under the low pressure in the reactor. However, it cannot be avoided

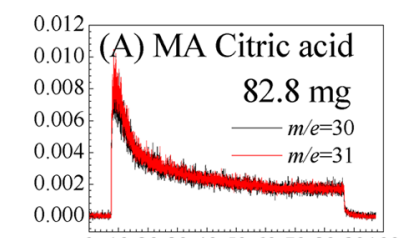

0102030405060708090100
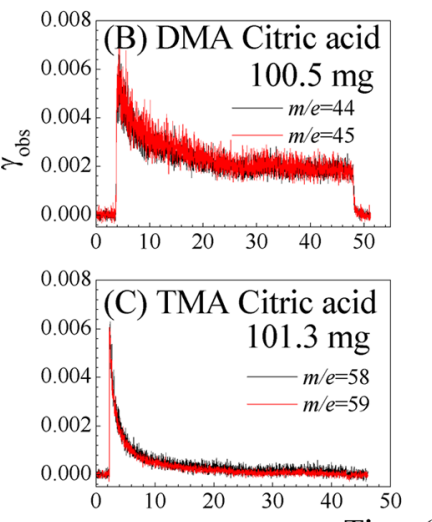

Time (min)

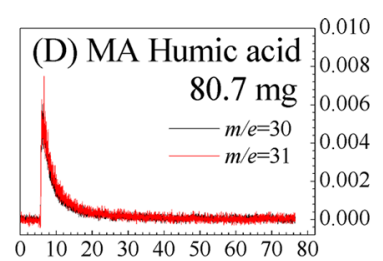

(E) DMA Humic acid 0.004

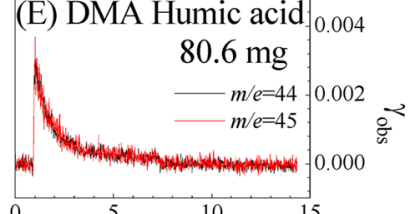

(F) TMA Humic acid 0.003

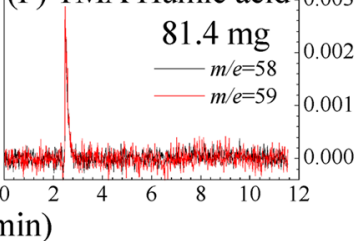

Figure 3. Observed uptake coefficients of amines at $298 \mathrm{~K}$ on (A)-(C) citric acid and (D)-(F) humic acid.

that reactive molecules diffuse into the underlying layers of a multilayer powder sample. Several papers have discussed this question $^{42-44}$ and also put forward several solutions, such as the KML model, ${ }^{42}$ the LMD model, ${ }^{43,44}$ the FPL model, ${ }^{45}$ and a model based on the Stokes-Einstein equation. ${ }^{46}$ Based on the KML model, Underwood et al. ${ }^{43}$ developed a linear mass dependent (LMD) model, which is widely used for data interpretation in Knudsen cell experiments. That is

$$
\gamma_{\mathrm{obs}}=\gamma_{\mathrm{t}} \cdot m_{\mathrm{eff}} \cdot S_{\mathrm{BET}} / A_{\mathrm{g}}
$$

or

$$
\gamma_{\mathrm{t}}=A_{\mathrm{g}} \cdot \text { Slope } / S_{\mathrm{BET}}
$$

where $\gamma_{\mathrm{t}}$ is the true uptake coefficient; $m_{\mathrm{eff}}$ is the effective sample mass $(\mathrm{mg}) ; S_{\mathrm{BET}}$ is the specific surface area of sample $\left(\mathrm{cm}^{2} \cdot \mathrm{mg}^{-1}\right) ; A_{\mathrm{g}}$ is the geometric area of the sample holder $\left(\mathrm{cm}^{2}\right)$; and Slope is the slope of the plot of $\gamma_{\mathrm{obs}}$ versus sample mass in the linear regime $\left(\mathrm{mg}^{-1}\right)$. Thus, the $\gamma_{\mathrm{t}}$ can be determined by measuring the $m_{\text {eff }}$ or probe depth of reactive molecules in a multilayer powder sample. The probe depth can be measured by the response of $\gamma_{\text {obs }}$ to sample mass if the powder samples can evenly cover the sample holder.

Figure 4 shows the changes of measured initial $\gamma_{\text {obs }}$ with sample mass. When the sample mass was lower than $40.0 \mathrm{mg}$, it was difficult to evenly cover the sample holder with acid particles because highly crystalline samples (with small specific surface area) were used in this study. Therefore, uptake experiments with sample masses lower than $40 \mathrm{mg}$ were not performed. For citric acid (Figure 5A-C), the $\gamma_{\mathrm{obs}}$ of amines shows independence of sample mass within experimental uncertainty. In previous work, it was also found that that the $\gamma_{\text {obs }}$ is independent of sample mass for uptake of amines on $\left(\mathrm{NH}_{4}\right)_{2} \mathrm{SO}_{4}, \mathrm{NH}_{4} \mathrm{HSO}_{4}, \mathrm{NH}_{4} \mathrm{NO}_{3}$, and $\mathrm{NH}_{4} \mathrm{Cl}^{14,16} \mathrm{~A}$ similar phenomenon was also observed for the uptake of $\mathrm{HNO}_{3}$ on soot ${ }^{47}$ and $\mathrm{N}_{2} \mathrm{O}_{5}$ and $\mathrm{H}_{2} \mathrm{O}$ on mineral dust. ${ }^{48,49}$ This implies a very small probe depth or a large true uptake coefficient of amines on citric acid. On the other hand, as discussed above, the reaction degree is lower than $0.05 \%$ even for the whole 
Table 1. Summaries of the Initial $\gamma_{\mathrm{obs}}$ of Amines on Citric Acid and Humic Acid at $298 \mathrm{~K}$

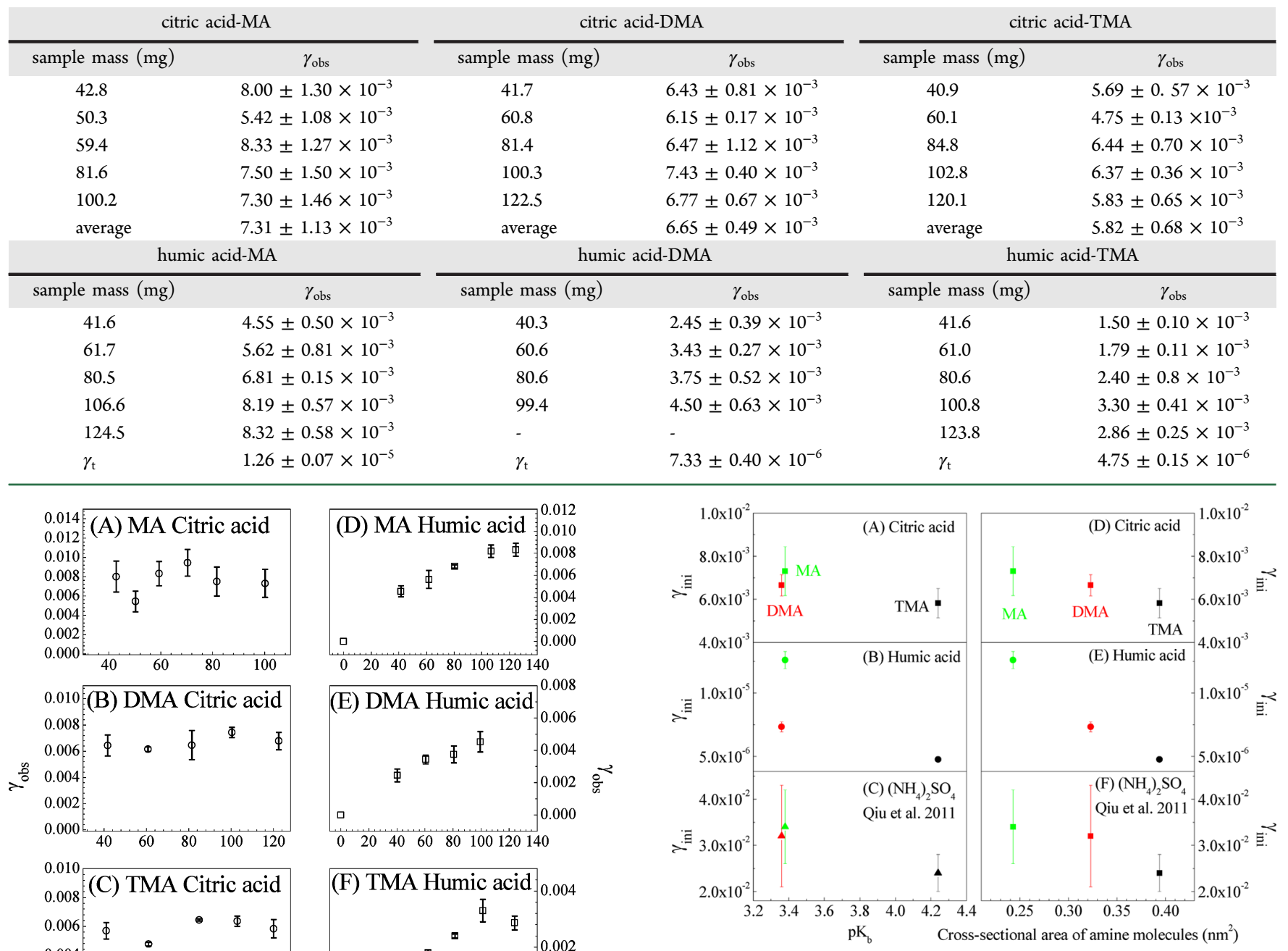

Figure 5. Relationship between $\gamma_{\text {ini }}$ and properties of amine molecules. The uptake coefficients of amines on $\left(\mathrm{NH}_{4}\right)_{2} \mathrm{SO}_{4}$ were from Qiu et al. $^{16}$

TMA on humic acid are measured to be $1.26 \pm 0.07 \times 10^{-5}$, $7.33 \pm 0.40 \times 10^{-6}$, and $4.75 \pm 0.15 \times 10^{-6}$, respectively. At the present date, no other data are available regarding the uptake of amines on carboxylic acids. The range of observed $\gamma$ of amines on citric acid is consistent with those for the displacement reaction with ammonium salts reported in the literature; ${ }^{14,15}$ while it is 2 orders of magnitude lower than the values for the acid-base reaction between amines and clusters of $\mathrm{NH}_{4} \mathrm{HSO}_{4}$ and sulfuric acid. ${ }^{11,12}$ For humic acid, $\gamma_{\mathrm{t}}$ is much lower than these reported uptake coefficients of amines on ammonium salts or sulfuric acid.

As discussed above, the response of $\gamma_{\text {obs }}$ to sample mass for citric acid is quite different from that for humic acid. This can be well explained using the KML model. In this model, the probe depth can be expressed as a complex function of several parameters including bulk density $\left(\rho_{\mathrm{b}}\right)$, true density $\left(\rho_{\mathrm{t}}\right)$, pore size $\left(r_{\mathrm{p}}\right)$, porosity $(\theta)$, and particle diameter $\left(d_{\mathrm{p}}\right)$ of powder sample, diffusion constant $\left(D_{\mathrm{f}}\right)$ of reactive molecules, and $\gamma_{\mathrm{t}}{ }^{42,43}$ Generally speaking, a small $D_{\mathrm{f}}$ and a large $\gamma_{\mathrm{t}}$ should result in a small probe depth and vice versa. Thus, the different response of $\gamma_{\text {obs }}$ to sample mass implies the discrepancy in the chemical nature between these two reaction systems. It should be pointed out that humic acid is a class of aromatic acids, in 
which phenolic and carboxylic groups are substituted on aromatic nuclei (Figure $\mathrm{S} 1)^{50}$ with $\mathrm{pK} K_{\mathrm{a} 1}$ around $5 ;^{51}$ while citric acid is a fatty acid with $\mathrm{p} K_{\mathrm{a} 1}$ of 3.1. ${ }^{52}$ Thus, for a given kind of amine, the stronger acidity of citric acid should explain the higher reactivity toward amines according to the linear free energy relationship. ${ }^{14}$ On the other hand, the neighbor group of carboxylic groups in humic acid is a stiff aromatic group, while it is a primary carbon in citric acid (Figure S1). Thus, for a given amine, the steric hindrance of humic acid should be stronger than that of citric acid. This may also contribute to the difference in reactivity of amines toward humic acid and citric acid.

Steric Effect. As discussed above, these amines have the same sequence in reactivity on either citric acid or humic acid, that is, $\gamma(\mathrm{MA})>\gamma(\mathrm{DMA})>\gamma(\mathrm{TMA})$. Qiu et al. ${ }^{16}$ also observed the same sequence for the heterogeneous reaction of amines on $\left(\mathrm{NH}_{4}\right)_{2} \mathrm{SO}_{4}$. According to the linear free energy relationship, an amine with stronger basicity should have a higher reactivity on a given substrate. Due to the electrophobic effect of the methyl group, TMA has the strongest basicity, with $\mathrm{p} K_{\mathrm{b}}$ of 4.24 compared to DMA $\left(\mathrm{p} K_{\mathrm{b}}=3.36\right)$ and MA $\left(\mathrm{p} K_{\mathrm{b}}=3.38\right) .{ }^{53}$ As shown in Figure 5A-C, however, the uptake coefficients of TMA are clearly lower than those of DMA and MA on citric acid, humic acid, and $\left(\mathrm{NH}_{4}\right)_{2} \mathrm{SO}_{4}{ }^{16}$ This is contrary to the linear free energy relationship for the acid-base reaction, which means other factors should be important in the reaction kinetics.

It should be pointed out that steric effect is another crucial factor governing the kinetics of organic reactions. The crosssectional area or volume can be used as a metric for the steric effect of a molecule. Using a space-filling model (CPK model) ${ }^{54}$ the cross-sectional areas of MA, DMA, and TMA were calculated to be $0.657,0.875$, and $1.067 \mathrm{~nm}^{2}$, respectively. Considering the uncertainty of the CPK model, we further calibrated the cross-sectional area using the model and experimental values of $\mathrm{Ar}, \mathrm{Kr}, \mathrm{Xe}, \mathrm{N}_{2}, \mathrm{H}_{2} \mathrm{O}, \mathrm{CH}_{3} \mathrm{OH}, \mathrm{C}_{2} \mathrm{H}_{6}$, $\mathrm{C}_{6} \mathrm{H}_{6}$, and $\mathrm{CO}_{2}{ }^{55}$ The calibrated cross-sectional area of $\mathrm{MA}$, DMA, and TMA are $0.243,0.323$, and $0.394 \mathrm{~nm}^{2}$, respectively. Figure 5D-E shows the correlation of the measured uptake coefficients on citric acid and humic acid and the cross-sectional area of amines. The uptake coefficients on citric acid and humic acid almost linearly decrease with the increase in the crosssectional area of the amines. According to the reported uptake coefficients on $\left(\mathrm{NH}_{4}\right)_{2} \mathrm{SO}_{4}{ }^{16}$ this linear relationship was also found. Thus, this confirms that the steric effect of amines has an important role in the heterogeneous reaction of amines on these substrates.

Atmospheric Implications. Field measurements have found that aminium salts and carboxylic acids are synchronously present in atmospheric particulate matter. ${ }^{1,8,22}$ Acidbase reactions between amines and $\mathrm{H}_{2} \mathrm{SO}_{4}$ or $\mathrm{HNO}_{3}$ and displacement reactions between amines and ammonium salts are widely accepted as the main source of particulate organic aminium salts. In real atmospheric particles, organic acids sometimes account for more than $30 \%$ of OA mass. ${ }^{1,22,23}$ In this study, the measured uptake coefficients of MA, DMA, and TMA on crystalline citric acid are comparable to that on $\left(\mathrm{NH}_{4}\right)_{2} \mathrm{SO}_{4}, \mathrm{NH}_{4} \mathrm{NO}_{3}$, and $\mathrm{NH}_{4} \mathrm{Cl}^{14}$ Thus, this result confirms that carboxylic acids should also participate in the formation of particulate amines through acid-base reactions. In atmospheric particles, diacids from $\mathrm{C}_{2}$ to $\mathrm{C}_{10}$ and ketocarboxylic acids from $\mathrm{C}_{2}$ to $\mathrm{C}_{9}$ are frequently detected. ${ }^{1,29,31,56}$ Although oxalic acid is the most abundant acid, ${ }^{1,29,31,56}$ its high vapor pressure makes it is impossible to measure the uptake coefficients of amines on oxalic acid using a Knudsen cell reactor. However, as found in this study, the acid with stronger acidity shows higher reactivity to amines. Oxalic acid has stronger acidity $\left(\mathrm{p} K_{\mathrm{a} 1}=1.23^{57}\right)$ than citric acid and humic acid. This means oxalic acid might have larger uptake coefficients than the values on citric acid and humic acid reported in this paper. Of course, although citric acid is highly similar to these aliphatic acids in chemical structure and atmospheric HULIS are strikingly similar to terrestrial humic and hulvic acids in chemical structure, ${ }^{58}$ differences still exist among them in molecular weight, aromatic moiety content, and surface activity. ${ }^{59}$ Thus, it needs to further investigate the reaction kinetics of amines with these abundant acids in ambient particles as well as the real HULIS using other methods in the future. On the other hand, the observed steric effect for amines suggests that heterogeneous uptake is unfavorable for amines with large substituents and/or a large number of substituents. It should be pointed out, however, that Wang et al. ${ }^{10}$ did not observe a difference for $\gamma$ of MA, DMA, and TMA on $\mathrm{H}_{2} \mathrm{SO}_{4}-\mathrm{H}_{2} \mathrm{O}$ film within their experimental uncertainties. Therefore, we think the steric effect observed in this study and that in Qiu's work ${ }^{16}$ means particle composition should also play an important role in the reactivity, and it cannot be simply extrapolated in ambient particles.

It should be pointed out that carboxylic acids are the main body of water-soluble organic compounds (WSOC). In the real atmosphere, thus, high relative humidity $(\mathrm{RH})$ might have an influence on this reaction due to the uptake of water or deliquescence of carboxylic acids. Recently, it has been found that aqueous salts of $\left(\mathrm{NH}_{4}\right)_{2} \mathrm{SO}_{4}, \mathrm{NH}_{4} \mathrm{HSO}_{4}$, and $\mathrm{NH}_{4} \mathrm{Cl}$ show a higher degree of exchange reaction toward TEA. ${ }^{13}$ This implies the uptake coefficients of amines on these samples might also be larger under ambient $\mathrm{RH}$ than these measured under dry conditions. In ambient environments, however, low $\mathrm{RH}$ conditions may also induce potential crystallization of these acids. For example, the deliquescence relative humidity (DRH) of oxalic acid is $93.0 \%$ at $297 \mathrm{~K}^{60}$ This means carboxylic acids in the solid phase might also have the chance to uptake amines. Thus, the results measured under dry conditions in this study suggest that uptake of amines by carboxylic acids should still take place even under extremely low RH. Recently, it has been found that aminium salts are thermally comparable or more stable than ammonium salts, ${ }^{8,61}$ and aminium salts in particlephase formed by heterogeneous reactions may enhance water uptake of particle. ${ }^{13,61}$ It means that heterogeneous reactions between amines and organic acids should play an important role in modification of particle properties. Thus, it is needs to further measure the reaction kenetics of amines with other organic acids in the future.

\section{ASSOCIATED CONTENT}

\section{Supporting Information}

The details of the Knudsen cell reactor. Structure of citric acid and the model structure of humic acid. This material is available free of charge via the Internet at http://pubs.acs.org.

\section{AUTHOR INFORMATION}

\section{Corresponding Author}

*Phone: +86-10-62849123. Fax: +86-10-62923563. E-mail: honghe@rcees.ac.cn.

\section{Notes}

The authors declare no competing financial interest. 


\section{ACKNOWLEDGMENTS}

This research was funded by the "Strategic Priority Research Program" of the Chinese Academy of Sciences (Grant No. XDB05010300) and National Natural Science Foundation of China (20937004 and 41275131).

\section{REFERENCES}

(1) Yang, H.; Xu, J. H.; Wu, W. S.; Wan, C. H.; Yu, J. Z. Chemical characterization of water-soluble organic aerosols at Jeju island collected during ACE-Asia. Environ. Chem. 2004, 1, 13-17.

(2) Wang, X. F.; Gao, S.; Yang, X.; Chen, H.; Chen, J. M.; Zhuang, G. S.; Surratt, J. D.; Chan, M. N.; Seinfeld, J. H. Evidence for high molecular weight nitrogen-containing organic salts in urban aerosols. Environ. Sci. Technol. 2010, 44 (12), 4441-4446.

(3) Laitinen, T.; Ehn, M.; Junninen, H.; Ruiz-Jimenez, J.; Parshintsev, J.; Hartonen, K.; Riekkola, M. L.; Worsnop, D. R.; Kulmala, M. Characterization of organic compounds in 10-to 50-nm aerosol particles in boreal forest with laser desorption-ionization aerosol mass spectrometer and comparison with other techniques. Atmos. Environ. 2011, 45 (22), 3711-3719.

(4) Kuhn, U.; Sintermann, J.; Spirig, C.; Jocher, M.; Ammann, C.; Neftel, A. Basic biogenic aerosol precursors: agricultural source attribution of volatile amines revised. Geophys. Res. Lett. 2011, 38 (16), L16811 DOI: 10.1029/2011GL047958.

(5) Ge, X.; Wexler, A. S.; Clegg, S. L. Atmospheric amines - Part I. A review. Atmos. Environ. 2011, 45 (3), 524-546.

(6) Cornell, S. E.; Jickells, T. D.; Cape, J. N.; Rowland, A. P.; Duce, R. A. Organic nitrogen deposition on land and coastal environments: a review of methods and data. Atmos. Environ. 2003, 37, 2173-2191.

(7) Bzdek, B. R.; Zordan, C. A.; Luther, G. W.; Johnston, M. V. Nanoparticle chemical composition during new particle formation. Aerosol Sci. Technol. 2011, 45 (8), 1041-1048.

(8) Smith, J. N.; Barsanti, K. C.; Friedli, H. R.; Ehn, M.; Kulmala, M.; Collins, D. R.; H.Scheckman, J.; Williams, B. J.; McMurry, P. H. Observations of aminium salts in atmospheric nanoparticles and possible climatic implications. Proc. Natl. Acad. Sci. U.S.A. 2010, 107, 6634-6639.

(9) Creamean, J. M.; Ault, A. P.; Ten Hoeve, J. E.; Jacobson, M. Z.; Roberts, G. C.; Prather, K. A. Measurements of aerosol chemistry during new particle formation events at a remote rural mountain site. Environ. Sci. Technol. 2011, 45 (19), 8208-8216.

(10) Wang, L.; Lal, V.; Khalizov, A. F.; Zhang, R. Heterogeneous chemistry of alkylamines with sulfuric acid: implications for atmospheric formation of alkylaminium sulfates. Environ. Sci. Technol. 2010, 44, 2461-2465.

(11) Bzdek, B. R.; Ridge, D. P.; Johnston, M. V. Amine exchange into ammonium bisulfate and ammonium nitrate nuclei. Atmos. Chem. Phys. 2010, 10 (8), 3495-3503.

(12) Bzdek, B. R.; Ridge, D. P.; Johnston, M. V. Size-dependent reactions of ammonium bisulfate clusters with dimethylamine. J. Phys. Chem. A 2010, 114, 11638-11644.

(13) Chan, L. P.; Chan, C. K. Displacement of ammonium from aerosol particles by uptake of triethylamine. Aerosol Sci. Technol. 2012, 46 (2), 236-247.

(14) Liu, Y.; Han, C.; Liu, C.; Ma, J.; Ma, Q.; He, H. Differences in the reactivity of ammonium salts with methylamine. Atmos. Chem. Phys 2012, 12 (11), 4855-4865.

(15) Lloyd, J. A.; Heaton, K. J.; Johnston, M. V. Reactive uptake of trimethylamine into ammonium nitrate particles. J. Phys. Chem. A 2009, 113 (17), 4840-4843.

(16) Qiu, C.; Wang, L.; Lal, V.; Khalizov, A. F.; Zhang, R. Heterogeneous reactions of alkylamines with ammonium sulfate and ammonium bisulfate. Environ. Sci. Technol. 2011, 45, 4748-4755.

(17) Bzdek, B. R.; Ridge, D. P.; Johnston, M. V. Amine reactivity with charged sulfuric acid clusters. Atmos. Chem. Phys. 2011, 11 (16), $8735-8743$.

(18) Zhao, J.; Smith, J. N.; Eisele, F. L.; Chen, M.; Kuang, C.; McMurry, P. H. Observation of neutral sulfuric acid-amine containing clusters in laboratory and ambient measurements. Atmos. Chem. Phys. 2011, 11 (21), 10823-10836.

(19) Murphy, S. M.; Sorooshian, A.; Kroll, J. H.; Ng, N. L.; Chhabra, P.; Tong, C.; Surratt, J. D.; Knipping, E.; Flagan, R. C.; Seinfeld, J. H. Secondary aerosol formation from atmospheric reactions of aliphatic amines. Atmos. Chem. Phys. 2007, 7 (9), 2313-2337.

(20) Kanakidou, M.; Seinfeld, J. H.; Pandis, S. N.; Barnes, I.; Dentener, F. J.; Facchini, M. C.; Van Dingenen, R.; Ervens, B.; Nenes, A.; Nielsen, C. J.; Swietlicki, E.; Putaud, J. P.; Balkanski, Y.; Fuzzi, S.; Horth, J.; Moortgat, G. K.; Winterhalter, R.; Myhre, C. E. L.; Tsigaridis, K.; Vignati, E.; Stephanou, E. G.; Wilson, J. Organic aerosol and global climate modelling: a review. Atmos. Chem. Phys. 2005, 5 (4), $1053-1123$.

(21) De Gouw, J.; Jimenez, J. L. Organic aerosols in the Earth's atmosphere. Environ. Sci. Technol. 2009, 43 (20), 7614-7618.

(22) Liu, S.; Day, D. A.; Shields, J. E.; Russell, L. M. Ozone-driven daytime formation of secondary organic aerosol containing carboxylic acid groups and alkane groups. Atmos. Chem. Phys. 2011, 11 (16), $8321-8341$.

(23) Zhang, Y. Y.; Müller, L.; Winterhalter, R.; Moortgat, G. K.; Hoffmann, T.; Pöschl, U. Seasonal cycle and temperature dependence of pinene oxidation products, dicarboxylic acids and nitrophenols in fine and coarse air particulate matter. Atmos. Chem. Phys. 2010, 10 (16), 7859-7873.

(24) Mohr, C.; DeCarlo, P. F.; Heringa, M. F.; Chirico, R.; Slowik, J. G.; Richter, R.; Reche, C.; Alastuey, A.; Querol, X.; Seco, R.; Peñuelas, J.; Jiménez, J. L.; Crippa, M.; Zimmermann, R.; Baltensperger, U.; Prévôt, A. S. H. Identification and quantification of organic aerosol from cooking and other sources in Barcelona using aerosol mass spectrometer data. Atmos. Chem. Phys. 2012, 12 (4), 1649-1665.

(25) Muller, L.; Reinnig, M. C.; Naumann, K. H.; Saathoff, H.; Mentel, T. F.; Donahue, N. M.; Hoffmann, T. Formation of 3-methyl1,2,3-butanetricarboxylic acid via gas phase oxidation of pinonic acid a mass spectrometric study of SOA aging. Atmos. Chem. Phys. 2012, 12 (3), 1483-1496.

(26) Falkovich, A. H.; Graber, E. R.; Schkolnik, G.; Rudich, Y.; Maenhaut, W.; Artaxo, P. Low molecular weight organic acids in aerosol particles from Rondônia, Brazil, during the biomass-burning, transition and wet periods. Atmos. Chem. Phys. 2005, 5 (3), 781-797.

(27) Agarwal, S.; Aggarwal, S. G.; Okuzawa, K.; Kawamura, K. Size distributions of dicarboxylic acids, ketoacids, alpha-dicarbonyls, sugars, WSOC, OC, EC and inorganic ions in atmospheric particles over Northern Japan: implication for long-range transport of Siberian biomass burning and East Asian polluted aerosols. Atmos. Chem. Phys. 2010, 10 (13), 5839-5858.

(28) Schmidl, C.; Bauer, H.; Dattler, A.; Hitzenberger, R.; Weissenboeck, G.; Marr, I. L.; Puxbaum, H. Chemical characterisation of particle emissions from burning leaves. Atmos. Environ. 2008, 42, 9070-9079.

(29) Stone, E. A.; Hedman, C. J.; Zhou, J.; Mieritz, M.; Schauer, J. J. Insights into the nature of secondary organic aerosol in Mexico City during the MILAGRO experiment 2006. Atmos. Environ. 2010, 44 (3), 312-319.

(30) Kawamura, K.; Semerd, R.; Imai, Y.; Fujii, Y.; Hayashi, M. Water soluble dicarboxylic acids and related compounds in Antarctic aerosols. J. Geophy. Res. 1996, 101 (D13), 18721-18728.

(31) Jung, J. S.; Kawamura, K. Enhanced concentrations of citric acid in spring aerosols collected at the Gosan background site in East Asia. Atmos. Environ. 2011, 45 (30), 5266-5272.

(32) Ivleva, N. P.; McKeon, U.; Niessner, R.; Pöschl, U. Raman microspectroscopic analysis of size-resolved atmospheric aerosol particle samples collected with an ELPI: soot, humic-like substances, and inorganic compounds. Aeros. Sci. Technol. 2007, 41, 655-671.

(33) Salma, I.; Mészáros, T.; Maenhaut, W.; Vass, E.; Majer, Z. Chirality and the origin of atmospheric humic-like substances. Atmos. Chem. Phys. 2010, 10 (3), 1315-1327.

(34) Liu, Y. C.; He, H. Experimental and theoretical study of hydrogen thiocarbonate for heterogeneous reaction of carbonyl sulfide on magnesium oxide. J. Phys. Chem. A 2009, 113, 3387-3394. 
(35) Liu, Y.; Ma, Q.; He, H. Comparative study of the effect of water on the heterogeneous reactions of carbonyl sulfide on the surface of $\alpha$ $\mathrm{Al}_{2} \mathrm{O}_{3}$ and MgO. Atmos. Chem. Phys. 2009, 9, 6273-6286.

(36) Liu, Y.; Ma, J.; He, H. Heterogeneous reactions of carbonyl sulfide on mineral oxides: mechanism and kinetics study. Atmos. Chem. Phys. 2010, 10, 10335-10344.

(37) Liu, Y.; Ma, J.; Liu, C.; He, H. Heterogeneous uptake of carbonyl sulfide onto kaolinite within a temperature range of 220-330 K. J. Geophys. Res. 2010, 115(D24311), doi:10.1029/2010JD014778.

(38) Underwood, G. M.; Li, P.; Usher, C. R.; Grassian, V. H. Determining accurate kinetic parameters of potentially important heterogeneous atmospheric reaction on solid particle with a Knudsen cell reactor. J. Phys. Chem. A 2000, 104, 819-829.

(39) Ullerstam, M.; Johnson, M. S.; Vogt, R.; Ljungström, E. DRIFTS and Knudsen cell study of the heterogeneous reactivity of $\mathrm{SO}_{2}$ and $\mathrm{NO}_{2}$ on mineral dust. Atmos. Chem. Phys. 2003, 3, 20432051.

(40) Tabor, K.; Gutzwiller, L.; Rossi, M. J. Heterogeneous chemical kinetics of $\mathrm{NO}_{2}$ on amorphous carbon at ambient temperature. J. Phys. Chem. A 1994, 98, 6172-6186.

(41) Liu, Y. C.; He, H.; Mu, Y. J. Heterogeneous reactivity of carbonyl sulfide on $\alpha-\mathrm{Al}_{2} \mathrm{O}_{3}$ and $\gamma-\mathrm{Al}_{2} \mathrm{O}_{3}$. Atmos. Environ. 2008, 42, 960-969.

(42) Keyser, L. F.; Moore, S. B.; Leu, M. T. Surface reaction and pore diffusion in flow-tube reactors. J. Phys. Chem. 1991, 95 (14), 54965502.

(43) Underwood, G. M.; Li, P.; Al-Abadleh, H. A.; Grassian, V. H. A Knudsen cell study of the heterogeneous reactivity of nitric acid on oxide and mineral dust particles. J. Phys. Chem. A 2001, 105, 66096620.

(44) Grassian, V. H. Chemical reactions of nitrogen oxides on the surface of oxide, carbonate, soot, and mineral dust particles: implications for the chemical balance of the troposphere. J. Phys. Chem. A 2002, 106 (6), 860-877.

(45) Hoffman, R. C.; Kaleuati, M. A.; Finlayson-Pitts, B. J. Knudsen cell studies of the reaction of gaseous $\mathrm{HNO}_{3}$ with $\mathrm{NaCl}$ using less than a single layer of particles at $298 \mathrm{~K}$ : a modified mechanism. J. Phys. Chem. A 2003, 107 (39), 7818-7826.

(46) Shiraiwa, M.; Ammann, M.; Koop, T.; Pöschl, U. Gas uptake and chemical aging of semisolid organic aerosol particles. Proc. Natl. Acad. Sci. U.S.A. 2011, 108 (27), 11003-11008.

(47) Munõz, M. S. S.; Rossi, M. J. Heterogeneous reactions of $\mathrm{HNO}_{3}$ with flame soot generated under different combustion conditions. Reaction mechanism and kinetics. Phys. Chem. Chem. Phys. 2002, 4, 5110-5118.

(48) Seisel, S.; Börensen, C.; Vogt, R.; Zellner, R. Kinetics and mechanism of the uptake of $\mathrm{N}_{2} \mathrm{O}_{5}$ on mineral dust at $298 \mathrm{~K}$. Atmos. Chem. Phys. 2005, 5, 3423-3432.

(49) Seisel, S.; Lian, Y.; Keil, T.; Trukhin, M. E.; Zellner, R. Kinetics of the interaction of water vapour with mineral dust and soot surfaces at $\mathrm{T}=298 \mathrm{~K}$. Phys. Chem. Chem. Phys. 2004, 6, 1926-1932.

(50) Niederer, C.; Goss, K.-U. Quantum chemical modeling of humic acid/air equilibrium partitioning of organic vapors. Environ. Sci. Technol. 2007, 41 (10), 3646-3652.

(51) Yang, H. B.; Yun, S. S. Interactions of $\mathrm{Eu}^{3+}$ and $\mathrm{Am}^{3+}$ with humic acid extracted from soil of Yongkwang in the Okchon Basin of the Korean Peninsula. J. Radioanal. Nucl. Chem. 2006, 270 (2), 435437.

(52) Karaffa, L.; Sandor, E.; Fekete, E.; Szentirmai, A. The biochemistry of citric acid accumulation by Aspergillus niger: a review. Acta. Microbiol. Immunol. Hung. 2001, 48 (3-4), 429-440.

(53) H. K. Hall, J. Correlation of the base strengths of amines. J. Am. Chem. Soc. 1957, 79, 5441-5444.

(54) Corey, R. B.; Pauling, L. Molecular models of amino ccids, peptides, and proteins. Rev. Sci. Instrum. 1953, 24 (8), 621-627.

(55) Gregg, S. J.; Sing, K. S. W. Adsorption surface area and porosity, 2nd ed.; Academic Press: London, 1982.
(56) Li, Y. C.; Yu, J. Z. Composition profile of oxygenated organic compounds and inorganic ions in PM2.5 in Hong Kong. Environ. Chem. 2010, 7, 338-349.

(57) Gelb, R. I. Conductometric determination of $\mathrm{pKa}$ values-oxalic and squaric acids. Anal. Chem. 1971, 43 (8), 1110-1113.

(58) Stone, E. A.; Hedman, C. J.; Sheesley, R. J.; Shafer, M. M.; Schauer, J. J. Investigating the chemical nature of humic-like substances (HULIS) in North American atmospheric aerosols by liquid chromatography tandem mass spectrometry. Atmos. Environ. 2009, 43 (27), 4205-4213.

(59) Graber, E. R.; Rudich, Y. Atmospheric HULIS: how humic-like are they? A comprehensive and critical review. Atmos. Chem. Phys. 2006, 6, 729-753.

(60) Brooks, S. D.; Wise, M. E.; Cushing, M.; Tolbert, M. A. Deliquescence behavior of organic/ammonium sulfate aerosol. Geophys. Res. Lett. 2002, 29 (19), 1917.

(61) Qiu, C.; Zhang, R. Physiochemical properties of alkylaminium sulfates: hygroscopicity, thermostability, and density. Environ. Sci. Technol. 2012, 46 (8), 4474-4480. 